\title{
Towards mineralogical and geochemical reference groups for some Bronze Age ceramics from Transylvania (Romania)
}

\author{
Volker HOECK ${ }^{1,2 *}$, Corina IONESCU², Lucreția GHERGARI² \& Carmen PRECUP² \\ ${ }^{1}$ University of Salzburg, Department of Geography and Geology, 34 Hellbrunnerstr., 5020 Salzburg, Austria \\ ${ }^{2}$ Babeş-Bolyai University, Department of Geology, 1 Kogălniceanu Str., 400084 Cluj Napoca, Romania
}

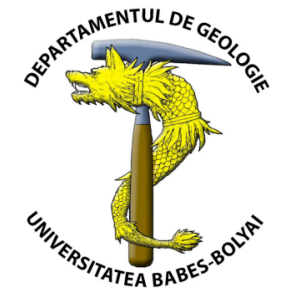

\begin{abstract}
Based on their chemical composition ceramic shards from three Bronze Age sites in Transylvania, i.e., Copăceni, Derşida and Palatca respectively, were distinguished by major, trace, and RE elements. Within the Copăceni samples, two subgroups (A and B) showing different chemistry and mineralogy were additionally separated out. The link between chemistry and mineralogy showed clearly the important contribution of the temper to the overall chemistry of the ceramic shards. In turn, the chemistry facilitated the provenance study of the raw materials, which were collected in the vicinity of the sites. In combination with the mineralogy of the ceramics, the chemical analyses can serve as a basis for a geochemical reference set used by further studies.
\end{abstract}

Key words: ancient ceramics, Bronze Age, mineralogy, geochemistry, archaeometry, Romania

\section{INTRODUCTION}

Compositionally, the ancient ceramics can be regarded as artificial rocks formed during a short living thermal event from clays mixed with tempering material, e.g., sands, potshards, and others.

The ceramic is a two-component system consisting of a major component, the clayey matrix and clasts as the second one. The latter originate mainly from the tempering material added by the potter and partly from the raw clay. The clasts may consist of one or more of the following types: crystalloclasts, lithoclasts, ceramoclasts and bioclasts (Ghergari et al., 1999; Ionescu and Hoeck, 2008). Chemical analyses have been used since several years in archaeometry to group and classify ancient ceramics, and for provenance studies (Yoon et al., 2001; Gliozzo and Memmi Turbanti, 2004; Mirti et al., 2004; Barone et al., 2005; Belfiore et al., 2007).

Taking into account the compositional complexity of the ceramics, the chemical analyses of ceramic shards have to be treated with utmost care in particular for the search of possible sources. The use of chemical data of whole ceramic fragments and their interpretation requires additionally a detailed mineralogical and petrographic study.

The paper presents the results of the first geochemical study on Bronze Age ceramics in Romania done in order to delineate distinctive features for each site as base for future analogies. We will show here that sound results can be achieved provided care is taken in handling the chemical data and connecting with the mineralogy and petrography.

\section{ARCHAEOLOGICAL AND GEOLOGICAL BACKGROUND}

In Romania and in particular in Transylvania, several Bronze Age settelements rich in ceramics artefacts, e.g. Ilişua, Copăceni, Palatca, Derşida were investigated. So far, only mineralogical-petrographic studies were carried out (Ionescu et al., 2005, 2006, 2007a, b; Precup et al., 2006 a, b; 2007, 2008; Precup, 2008). The present study deals with ceramic potshards from Copăceni, Derşida and Palatca (Fig. 1), provided by the National Museum of History of Transylvania from Cluj-Napoca.

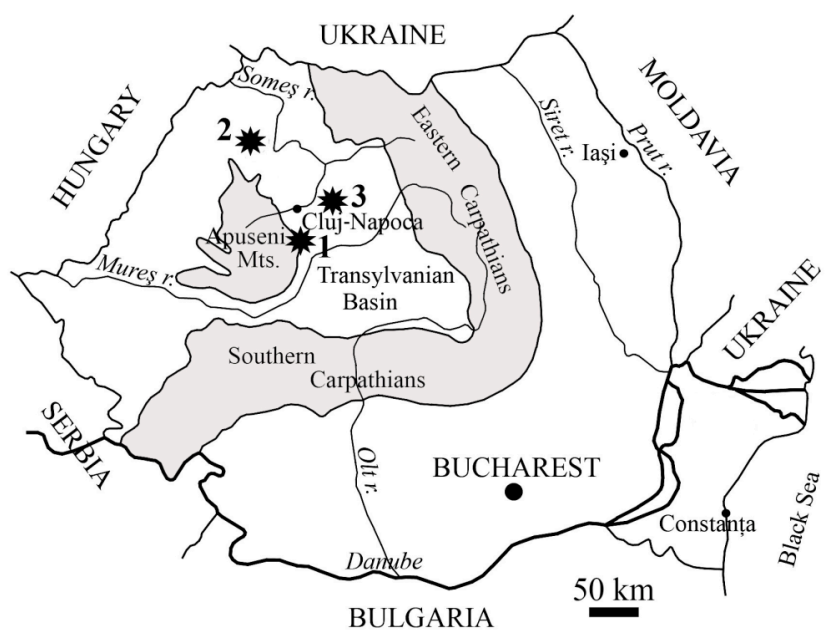

Fig. 1. Location of the Copăceni - Early Bronze Age (1), Derşida - Middle Bronze Age (2) and Palatca - Late Bronze Age (3) sites within the Romanian territory. 
The Copăceni site is located $25 \mathrm{~km}$ south of ClujNapoca (site 1 in Fig.1) and was dated as Early Bronze in age ( 2000 to 1600 B.C.). Small and medium-sized ceramic table ware was found at the site. The high amount and typological diversity of the ceramics remnants, and the finding of similar ware in several archaeological sites in Transylvania supported the outline of the most important cultural phenomenon of the second half of the Early Bronze age, i.e. the „Copăceni-type” (Rotea, 1993, 1997). Geologically, the site is located at the contact of the Transylvanian Depression with the units of the Northern Apuseni Mts. and Southern Apuseni Mts., respectively (Lupu et al., 1967). The Cenozoic sediments of the Transylvanian Depression are represented by Palaeocene continental red clays, Eocene marls, clays, limestones and sandstones, Badenian conglomerates, limestones \pm celestine and barite (Imreh and Imreh, 1959; Savul et al., 1964), gypsum, salt, volcanic tuffs and sandstones, Sarmatian marls, sandy marls, sandstones and sands, Upper Pleistocene and Holocene gravels and sands. Lithologically, the units belonging to the Northern Apuseni Mts. (Săndulescu, 1984; Pană et al., 2002; Balintoni et al., 2009) include Palaeozoic and Mesozoic metamorphics (micaschists, quartzites, gneises, granitoids, amphibolites, skarns, marbles) and Late Cretaceous-Early Palaeogene magmatites (granodiorites, dacites, diorites, andesites). The Southern Apuseni Mts. units consists of Late Jurassic Island Arc Volcanics (basaltic andesites to rhyolites, and associated pyroclastics), overlain by Tithonian platform limestones.

The Derşida site is located in western Romania, $90 \mathrm{~km}$ in straight line NW of Cluj-Napoca (site 2 in Fig. 1). The ceramic findings consist of various table ware, decorated with incisions and assigned to the „Wietenberg Culture” (Chidioşan, 1980) of Middle Bronze Age ( 1600 - 1300 B.C.). Geologically, the area belongs to the eastern part of the Pannonian Basin. Mainly Badenian conglomerates, sandstones, marls and limestones, Sarmatian sandstones, marls, conglomerates and sands, Pannonian clays, marls, sands and gravels, Upper Pleistocene sands, gravels, clays and loess and Holocene gravels and sands occur in the area (Bleahu et al 1966, Giuşcă et al., 1967; Răileanu et al., 1967). Towards southeast, in the Meseş Mts. (Northern Apuseni Mts.), the metamorphics consisting of micaschists, garnet-micaschists, amphibolites, quartzites form a fault bounded, NE-SW oriented narrow wedge (Giuşcă et al., 1967; Răileanu et al., 1967). Late Cretaceous-Early Paleogene dacitic and Neogene andesitic small bodies can be also found in the Meseş Mts.

The Palatca site is located $30 \mathrm{~km}$ in straight line ENE from Cluj-Napoca (site 3 in Fig. 1), in the Transylvanian Basin. The site is dated as Late Bronze Age ( 1300 to 1000 B.C.) and several thousands fragments of various decorated pottery were found (Rotea, 1997). Geologically, around the site only sedimentary formations such as Badenian marls, sandstones, salt and volcanic tuffs, and Sarmatian marls, sands and gravel are found. The Holocene sands and gravels fill in the small valleys. Towards west, at $10 \mathrm{~km}$ in straight line, the Someş river shows large terasses, covered by Upper Pleistocene sands and gravels (Răileanu et al., 1967). In the Badenian formations the „Dej tuff” level occurs, cropping out west of Palatca (Ciupagea et al., 1970; Szakacs, 2000). In the close vicinity of the site, the Sarmatian formations contain, intercalated between marls and sands, the "Ghiriş tuff”, compositionally a pyroxene andesite, with a high amount of amphiboles and pyroxenes (Ciupagea et al., 1970).

\section{SAMPLES AND METHODS}

For the identification of the mineral phases, 16 thin sections were cut from Copăceni, 22 from Derşida and 28 from Palatca samples respectively, were studied in polarized light. Due to the small size of the shards, only 5 ceramic samples from Derşida, 5 samples from Copăceni and 7 samples from Palatca were chemically analyzed for major, minor, trace and RE elements at the Acme Analytical Laboratories Ltd. Vancouver (Canada). For $\mathrm{SiO}_{2}, \mathrm{Al}_{2} \mathrm{O}_{3}, \mathrm{Fe}_{2} \mathrm{O}_{3}, \mathrm{CaO}, \mathrm{MgO}, \mathrm{Na}_{2} \mathrm{O}, \mathrm{K}_{2} \mathrm{O}, \mathrm{MnO}, \mathrm{TiO}_{2}$, $\mathrm{P}_{2} \mathrm{O}_{5}, \mathrm{MnO}, \mathrm{Cr}_{2} \mathrm{O}_{3}, \mathrm{Ba}, \mathrm{Ni}, \mathrm{Sc}$ analyses by ICP-ES (Spectro Ciros Vision) and the ICP-MS analyses (PerkinElmer-Elan 6000/9000) for REE and incompatible elements were done by $\mathrm{LiBO}_{2} / \mathrm{Li}_{2} \mathrm{~B}_{4} \mathrm{O}_{7}$ fusion in a graphite crucible at $980^{\circ} \mathrm{C}$ and subsequently dissolution in $\mathrm{HNO}_{3}$ $(5 \%)$. This procedure was also applied for $\mathrm{Co}, \mathrm{Cs}, \mathrm{Ga}, \mathrm{Hf}$, $\mathrm{Nb}, \mathrm{Rb}, \mathrm{Sr}, \mathrm{Ta}, \mathrm{Th}, \mathrm{U}, \mathrm{V}, \mathrm{W}, \mathrm{Zr}, \mathrm{Y}, \mathrm{La}, \mathrm{Ce}, \mathrm{Pr}, \mathrm{Nd}, \mathrm{Sm}$, $\mathrm{Eu}, \mathrm{Gd}, \mathrm{Tb}, \mathrm{Dy}, \mathrm{Ho}, \mathrm{Er}, \mathrm{Tm}, \mathrm{Yb}$, and Lu. The precious and base metals $2+(\mathrm{Mo}, \mathrm{Cu}, \mathrm{Pb}, \mathrm{Zn}, \mathrm{Ni}, \mathrm{As})$ were digested in aqua regia and also analyzed by ICP-MS. Loss of ignition (LOI) was determined by weight loss after ignition at $950^{\circ} \mathrm{C}$ for 90 minutes. The $\mathrm{C}_{\text {tot }}$ was determined by a LECO furnace.

\section{RESULTS}

\section{Mineralogy and petrography}

For a sound interpretation of the geochemistry of the ceramics, a brief presentation of the mineralogy and petrography is neccessary.

The Copăceni pottery has red or dark brown colour, either homogeneously distributed across the ceramic body or forming a "sandwich-type" zoning. The observations made on thin sections in polarized light show two main ceramic types:

- Type A ceramics (Fig. 2a), composed of an opaque and more or less isotropic, amorphous clayish matrix. Embedded are mainly clasts of quartz and plagioclase, as well as muscovite. Moreover, biotite, amphiboles, pyroxenes, epidote, allanite(?) and opaque minerals were identified. As lithoclasts, fragments of micaschists, quartzites, skarn-like rocks and granitoids are visible.

- Type B ceramics (Fig. 2b) consists of a translucent, relatively anisotropic matrix. The crystalloclasts are composed of quartz, plagioclase and rare K-feldspar. Muscovite lamellae and rare amphibole can be seen. The lithoclasts consist of fragments of volcanic acidic tuffs, various volcanics (rhyolites, basaltic andesites, dacites) and chert. The texture in either preferentially oriented, parallel to the ceramic wall or shows a random orientation of lamellar phases and pores. One of the main characteristics for this ceramic type is the presence of high amount of plagiclase and volcanic acidic tuff fragments.

The Derşida samples show a wide range of colours, from light brown to dark brown, in general inhomogeneously distributed within the ceramic wall. The mineralogical study revealed a microcrystalline anisotropic 
(Fig. 2c), sometimes amorphous isotropic (Fig. 2d) clayish matrix. Small crystalloclasts of quartz, K-feldspar, plagioclase, muscovite, rare amphibole and pyroxene, besides large-sized various lithoclasts are present. The most characteristic are the amphibolitic schists, quartzites, granodiorites and altered andesite fragments. Soil concretions are also identified, as well as rare ceramoclasts. The texture is in general unoriented, with few exceptions when it shows a slight parallel arrangement of lamellar minerals and pores.

The Palatca samples show an highly inhomogeneouslycoloured ceramic body, ranging from red to almost black. Very often a sandwich-type zoning can be noticed across the ceramic wall. The wide range of compositions do not allow to separate out some mineralogical-petrographic subgroups.
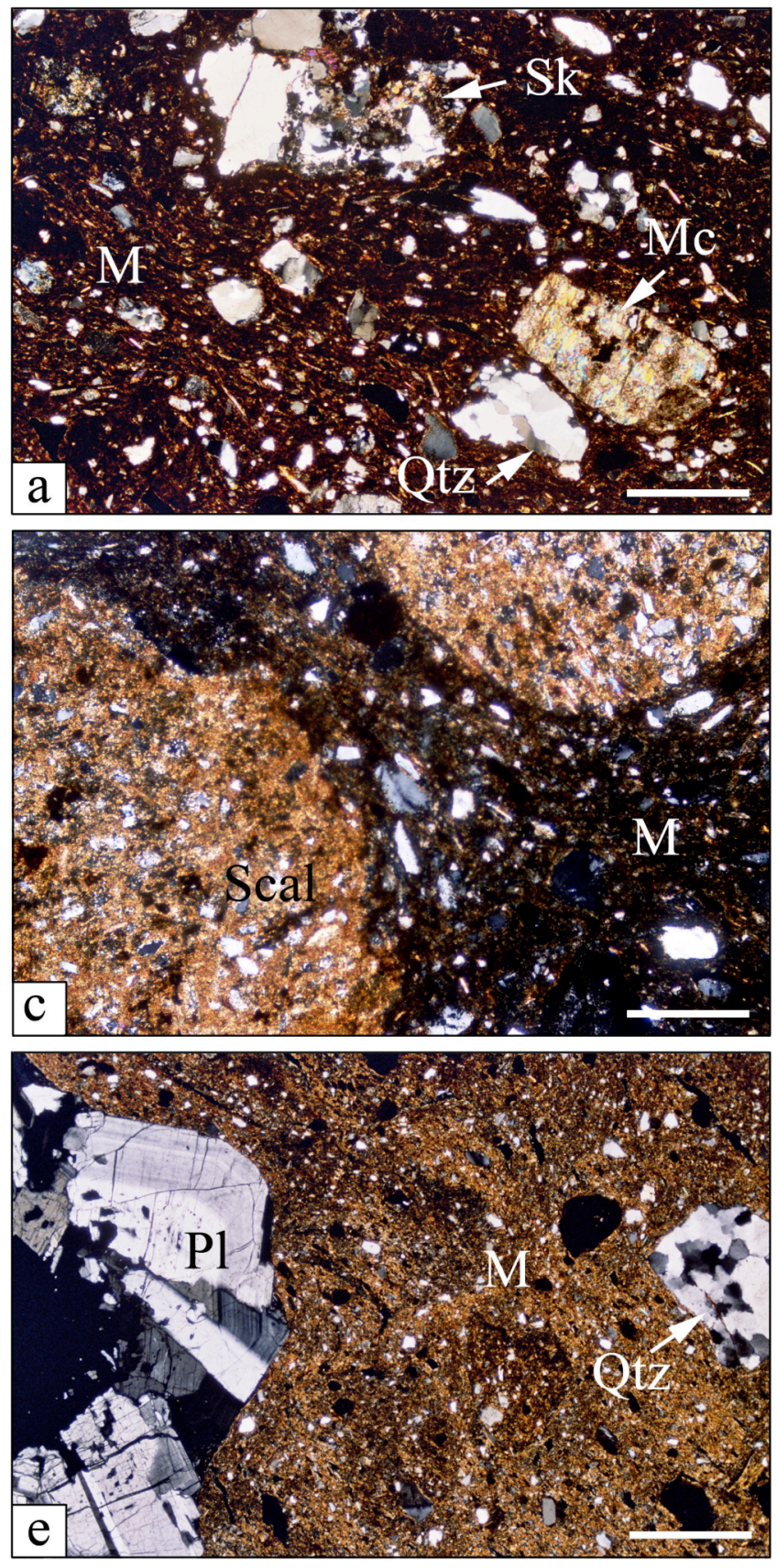

Fig. 2. Microphotographs of thin sections of Bronze Age ceramics (polarized light, crossed polarizators, scale bar =0.5 mm. a) Sample 36-5 Copăceni A. Almost isotropic matrix (M) comprising clasts of quartzite (Qtz), diopside skarn (Sk) and micaschist (Mc); b) Sample 36-3 Copăceni B. Anisotropic, oriented matrix (M), with small crystalloclasts of quartz (Qtz) and large clasts of volcanic tuffs (Vt); c) Sample 35-1 Derşida. Isotropic matrix (M) enclosing large lithoclasts of calcareous silt (Scal); d) Sample 35-15 Derşida. Small crystalloclasts of quartz and large clasts of quartzites (Qtz) in an isotropic matrix (M); e) Sample 37-14 Palatca. Anisotropic matrix (M) including a very large plagioclase clast (Pl) and a quartzitic lithoclast (Qtz); f) Sample 37-10 Palatca. Quartz crystalloclasts (white and shades of gray in the image) and various ceramoclasts $(C c)$ embedded in an anisotropic matrix $(M)$.
The matrix is either microcrystalline-anisotropic (Fig. 2e, f) or almost amorphous-isotropic. The clasts vary from sample to sample. Quartz, muscovite, K-feldspar and plagioclase (Fig. 2e) and various lithoclasts, such as quartzites, clays, sandstones are common. Andesite and pyroxenes are restricted to two samples (37-1 and 37-14). Ceramoclasts occur frequently (Fig. 2f). Calcite is rare and occurs as burial deposition on fissures and voids.

As a general remark, the ratio between the lutitic/partly siltic grain size (matrix) over silt+arenite+rudite grains (clasts) is higher in Copăceni (54\%) and Palatca (56\%) compared with Derşida (48\%). In individual samples this ratio might be reversed. The values are given as arithmetic mean.
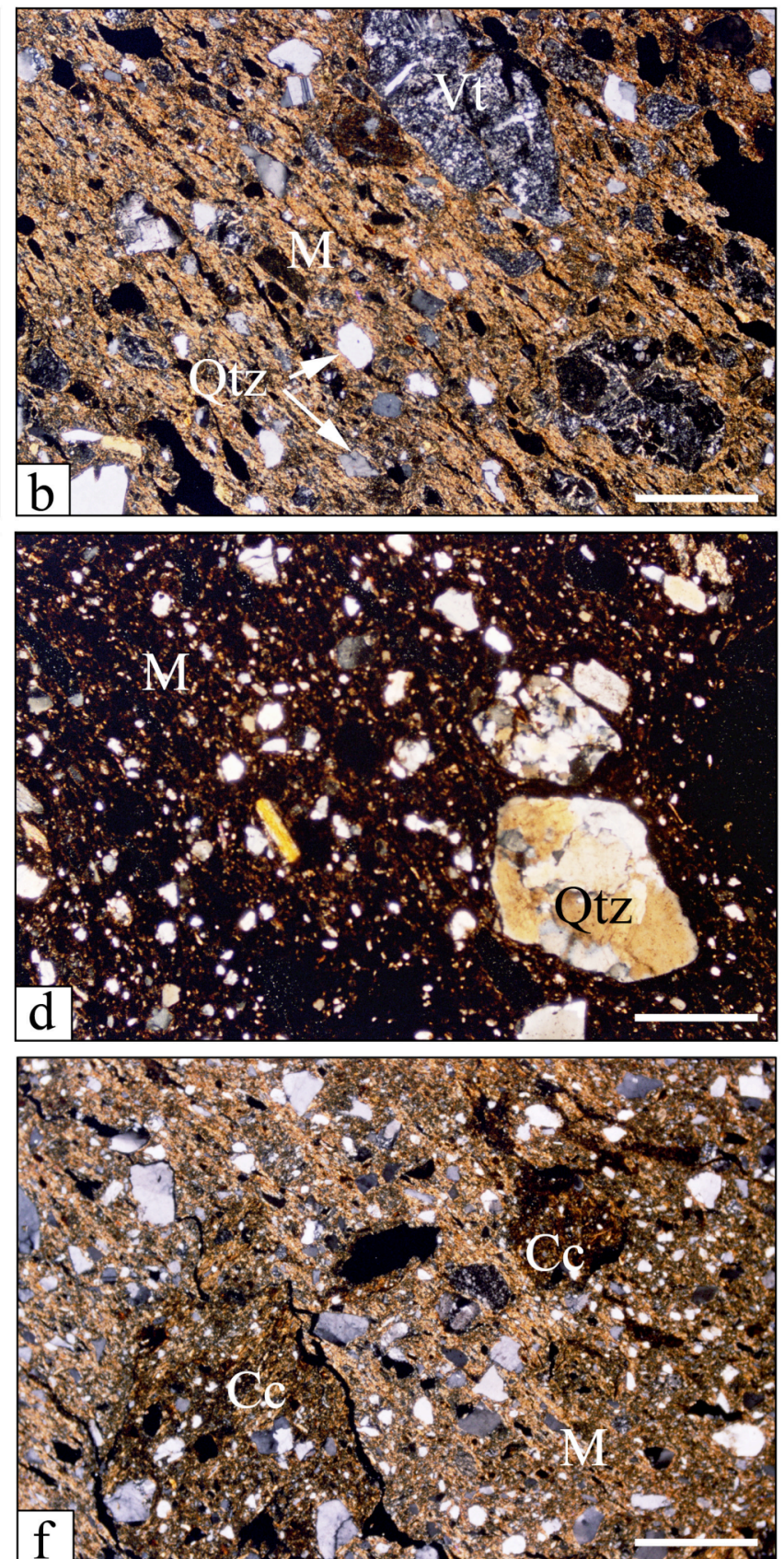

Studia UBB, Geologia, 2009, 54 (2), 41 -51 


\section{Geochemistry}

The original geochemical analyses for the ceramics including the major, trace and RE elements are listed in Table 1. All samples show, based on $\mathrm{SiO}_{2}$ content, an intermediate to acidic chemistry. The $\mathrm{CaO}$ content, ranging from $1.30 \%$ to $3.0 \%$, is relatively low. Some elements e.g., $\mathrm{Al}$ and $\mathrm{Mg}$ show only little variation. Others, such as K (Figs. 3a-c), Fe (Fig. 3d), Ti, Sr, Zr, Cr and $\mathrm{Co}$ show significant variation and can be used for grouping and classification. There is only a weak covariation among the major elements. A first inspection of the data from all sites i.e., Copăceni, Derşida and Palatca shows that they are spread to a certain extent not only between the groups but also within the groups. Among these, $\mathrm{Na}, \mathrm{K}, \mathrm{Ca}$ and $\mathrm{P}$ within the major element group and $\mathrm{Ni}, \mathrm{Co}, \mathrm{Cr}, \mathrm{Th}, \mathrm{Sc}, \mathrm{Zr}$, or $\mathrm{Ce}$ as trace elements respectively, have a certain potential of discrimination. Due to their similar geo-chemical properties many trace elements such as $\mathrm{Cr} / \mathrm{Ni}, \mathrm{Cr} / \mathrm{Co}$ (Fig. 4a), La/Ce (Fig. 4b), V/Ti, V/Sc (Fig. 4c), Sc/Ti, Nb/Zr (Fig. 4d), Th/Ta, Zr/Hf and others are positively correlated. For example, the compatible elements such as $\mathrm{Cr}, \mathrm{Ni}$ and $\mathrm{Co}$ are enriched during magmatic processes in minerals such as olivine, pyroxenes, amphiboles or spinels. When used as temper these elements contribute to the overal chemical budget of the ceramics. In a similar way the amount of Sc, V and to some extent $\mathrm{Ti}$ in ceramics can increase by adding a temper rich in amphibole, pyroxene, magnetite or ilmenite. The same holds for feldspar in respect to K, Na, Ba, Sr. On the other hand, some elements might be diluted by the frequent addition of quartz or quartzites as temper. Thus, the mineralogy of the temper plays an important role in the chemistry of the ceramics determining the relative enrichment or depletion of an element upon the mixture with the clayish matrix.

For the further discussion of the chemistry, the ceramics were grouped according to their original sites i.e. Copăceni, Derşida and Palatca, respectively. The samples from Derşida and Palatca show a considerable spread in major and trace elements, a division in subgroups is not discernable. The five Copăceni samples show a bi-modal element distribution (Table 1). Two shards (36-5 and 36-8) are markedly different form the others in respect to a large number of elements. They are significantly enriched in $\mathrm{Fe}, \mathrm{Ti}, \mathrm{Al}, \mathrm{Cr}, \mathrm{Ni}, \mathrm{Co}, \mathrm{Cu}$, $\mathrm{Zn}, \mathrm{Sc}, \mathrm{Nb}, \mathrm{Zr}, \mathrm{Y}, \mathrm{V}, \mathrm{Hf}, \mathrm{Cs}$, and $\mathrm{Rb}$, but relatively depleted in $\mathrm{Si}, \mathrm{K}$, and $\mathrm{Sr}$ compared to the three other shards (samples 36-1, 36-3, 36-7). Based on the systematic change, we grouped the former as Copăceni A and the rest as Copăceni B. This is in accordance with the mineralogy and petrography of Copăceni as described above. The major difference is the frequent occurrence of biotite, amphibole, pyroxene and metamorphics in the Copăceni A, compared with plagioclase, muscovite, volcanic acidic tuffs and volcanics in the Copăceni B ceramics.

\section{DISCUSSION}

The chemical analyses of ceramic shards should serve multiple purposes as: a) a characterization of a certain group of ceramics, b) possible separation between different groups, c) possible classification within one group and d) for provenance studies. Chemistry is not an independent variable, each chemical variation reflects the Studia UBB, Geologia, 2009, 54 (2), 41 - 51 differences in the mineralogical composition and the amount of matrix and temper.

\section{Major Elements}

The classical $\mathrm{K}_{2} \mathrm{O}+\mathrm{Na}_{2} \mathrm{O}$ vs. $\mathrm{SiO}_{2}$ diagram (Fig. 3a) highlights in particular the potential of the alkali elements to separate the groups: the Copăceni samples A and B are nicely separated from the Derşida samples by the significant higher alkali content of the former. The $\mathrm{Na}_{2} \mathrm{O}$ vs. $\mathrm{K}_{2} \mathrm{O}$ diagram (Fig. $3 \mathrm{~b}$ ) sorts out to a certain extent all three groups. The grouping is not perfect, but the Derşida samples exhibit a slightly higher $\mathrm{Na}_{2} \mathrm{O} / \mathrm{K}_{2} \mathrm{O}$ ratio than the others. This is due to the low potassium content in the matrix (also shown by the electron microprobe analyses unpublished data). Copăceni $\mathrm{A}$ and $\mathrm{B}$ have a tendency towards higher $\mathrm{Na}_{2} \mathrm{O}$ and $\mathrm{K}_{2} \mathrm{O}$ compared to Palatca.

Several other element ratios have been proposed for characterization of sediments in terms of provenance. For example the $\mathrm{Al}_{2} \mathrm{O}_{3} / \mathrm{TiO}_{2}$ ratio (Nagarajan et al., 2907) or the $\mathrm{K}_{2} \mathrm{O} / \mathrm{Al}_{2} \mathrm{O}_{3}$ ratio (Fig. 3c, Table 1) and the Index of Compositional Variability (Cox et al., 1995).

The latter, in short ICV, is calculated from $\left(\mathrm{Fe}_{2} \mathrm{O}_{3}+\mathrm{K}_{2} \mathrm{O}+\mathrm{Na}_{2} \mathrm{O}+\mathrm{CaO}+\mathrm{MgO}+\mathrm{MnO}+\mathrm{TiO}_{2}\right) / \mathrm{Al}_{2} \mathrm{O}_{3}$ and it may range from 0.01 (clay minerals) to 1000 (non-clay silicates); it might well be applied also for ceramics. Values between 0.75 and 0.95 calculated for our samples indicate some contributions from minerals such as muscovite, feldspars and/or amphiboles as observed in the thin sections. The values are not significantly different between the groups (Table 1). The variation within the one group is in the same range. The $\mathrm{K}_{2} \mathrm{O} / \mathrm{Al}_{2} \mathrm{O}_{3}$ ratio (Fig. 3c) is lowest in Derşida (0.13 to 0.16), variable in Palatca and Copăceni A $(0.12$ to 0.20$)$ but higher in Copăceni $\mathrm{B}(0.22-0.27)$. The low $\mathrm{K}_{2} \mathrm{O} / \mathrm{Al}_{2} \mathrm{O}_{3}$ ratio can be explained by the very low $\mathrm{K}_{2} \mathrm{O}$ content combined with a relatively high $\mathrm{CaO}$ in the matrix (see above). The $\mathrm{Al}_{2} \mathrm{O}_{3} / \mathrm{TiO}_{2}$ ratio is larger than 30 for Copăceni $\mathrm{B}$ (due to the more acidic clasts) and between 16 and 20 for the rest of the samples.

\section{Trace elements}

While Copăceni B samples are easily distinguished by some major elements, the other groups are more difficult to be separated out. Copăceni $\mathrm{A}$ has the highest $\mathrm{Fe}_{2} \mathrm{O}_{3}$ content (Fig. 3d) and additionally the highest Co (Fig. 4a) and $\mathrm{Ce}$ (Fig. 4b) values as well as high concentrations of $\mathrm{Cu}, \mathrm{Zn}, \mathrm{Ti}, \mathrm{V}$ and Sc (Fig. 4c). This is at least partly due to the opaque minerals as well as to the relatively high amount of pyroxene and amphiboles as part of the temper. Both subgroups of Copăceni have one specific characteristic, the high $\mathrm{Sr}$ content which is, with 500 to $2000 \mathrm{ppm}$, a multiple of those from Derşida and Palatca (100-250 ppm). The high Sr content (Fig. 4e) in Copăceni is most likely caused by the specific localization in close vicinity of the site of the celestine-bearing Badenian formations (Imreh and Imreh, 1959; Savul et al., 1964).

The differentiation among Derşida and Palatca is more difficult to obtain. Both groups overlap to a wide extent and are rarely clearly separated. Among the major elements, only the $\mathrm{Na}_{2} \mathrm{O} / \mathrm{K}_{2} \mathrm{O}$ ratio (Fig. 3b) shows a certain potential for classifying as shown above. In a similar way as the alkalies, the $\mathrm{Zr} / \mathrm{Nb}$ ratio (Fig. $4 \mathrm{~d}$ ) separates both groups with a value of below 18 for Derşida and above 18 for Palatca. 


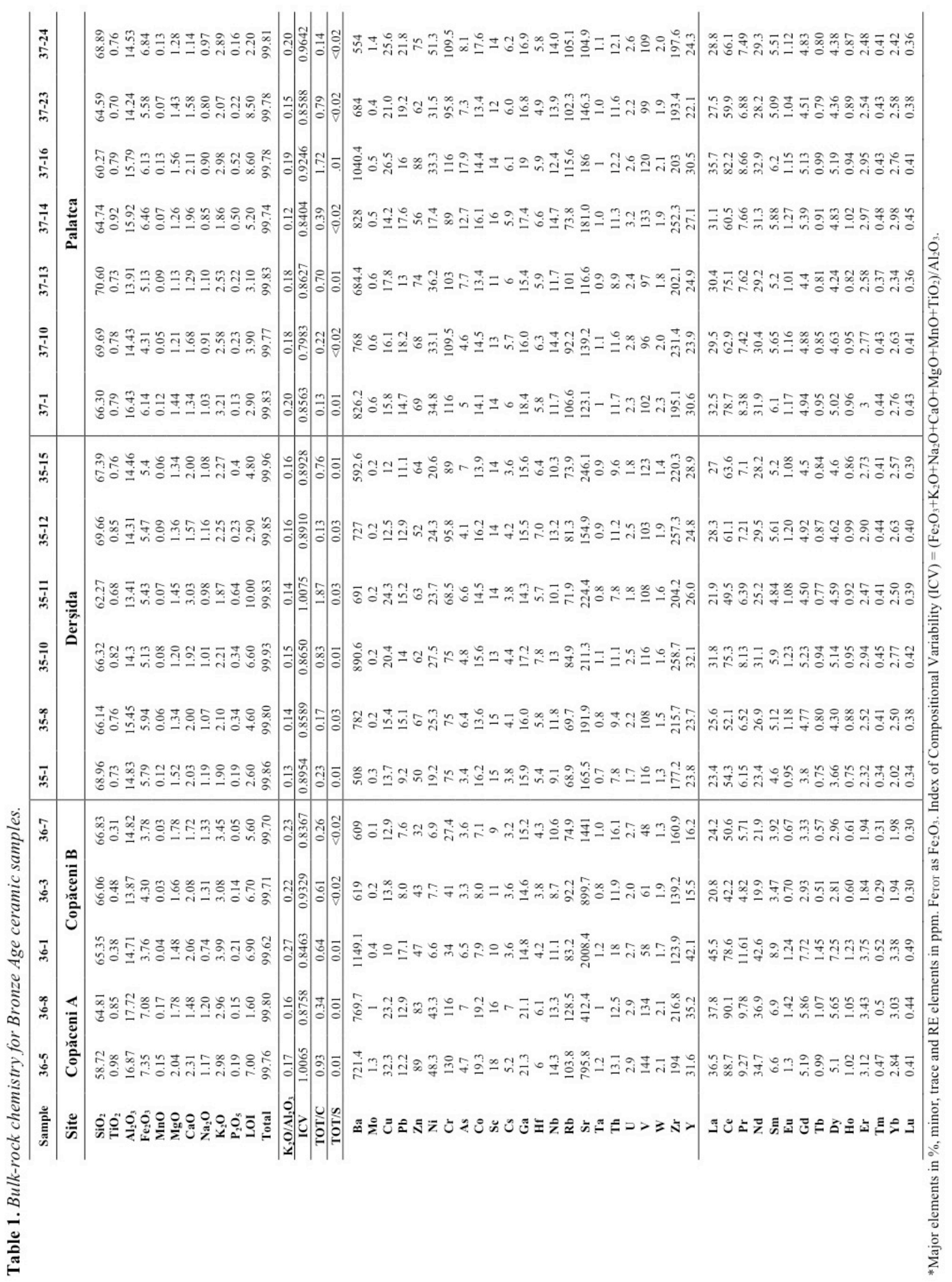




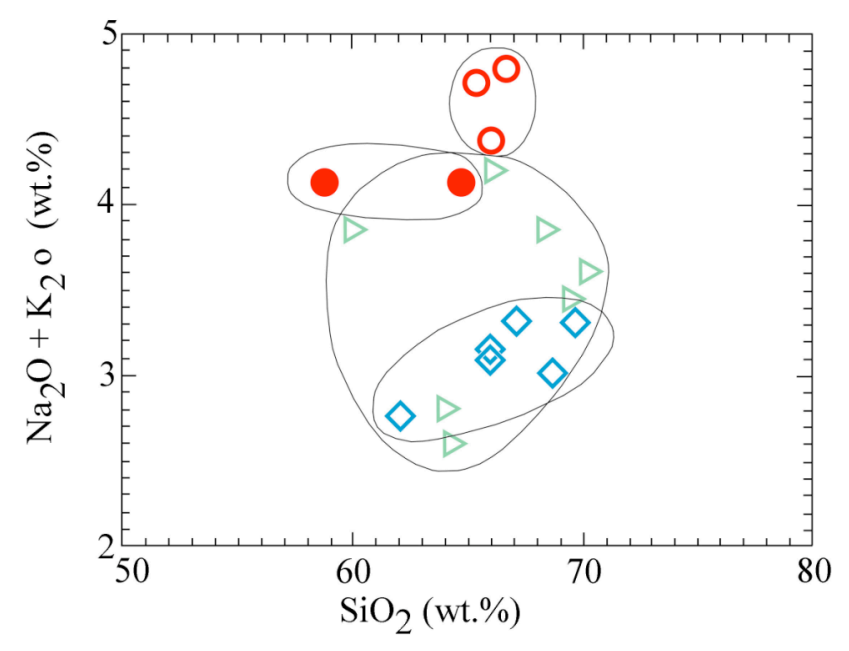

a)

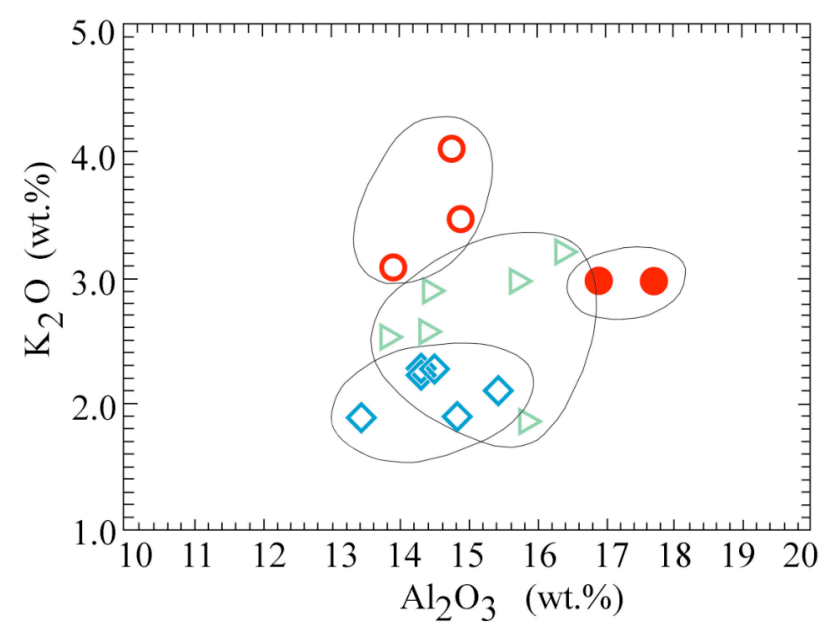

c)

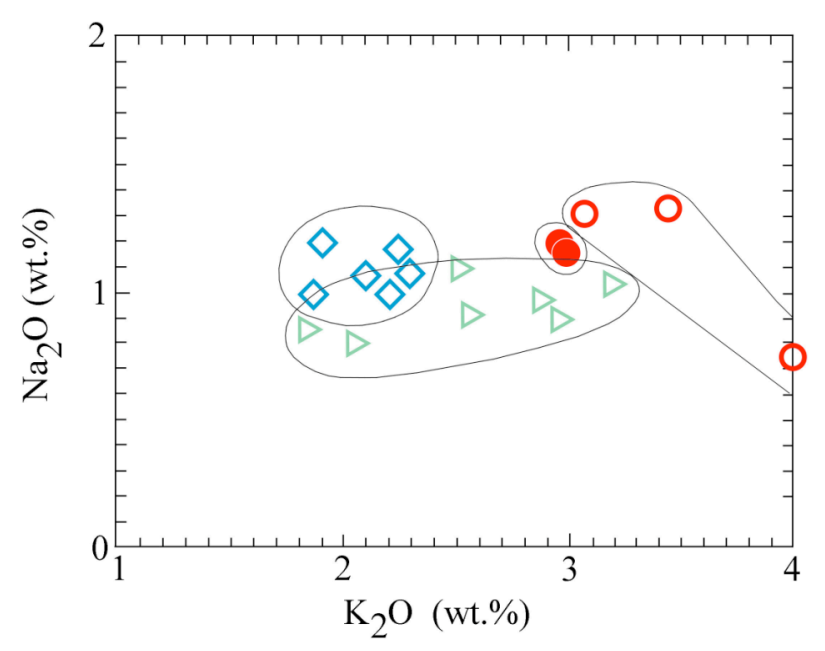

b)

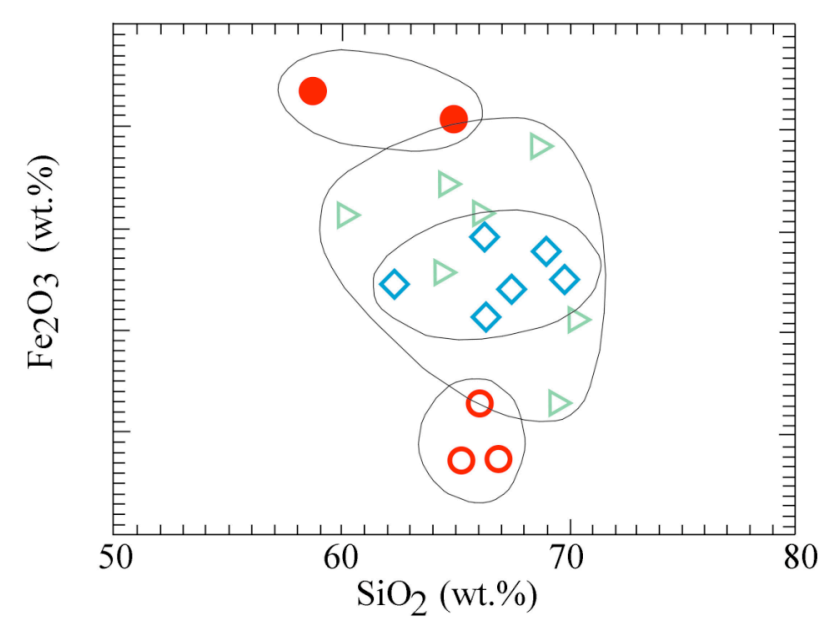

d)

Fig. 3. Plot of the ceramics composition in the a) $\mathrm{SiO}_{2} v \mathrm{~s}$. $\mathrm{Na}_{2} \mathrm{O}+\mathrm{K}_{2} \mathrm{O}$, b) $\mathrm{K}_{2} \mathrm{O}$ vs. $\mathrm{Na}_{2} \mathrm{O}$, c) $\mathrm{Al}_{2} \mathrm{O}_{3}$ vs. $\mathrm{K}_{2} \mathrm{O}$ and d) $\mathrm{SiO}_{2} v \mathrm{~s}$. $\mathrm{Fe}_{2} \mathrm{O}_{3}$ diagrams. Legend: full red circles - Copăceni A, empty red circles - Copăceni B, blue diamonds - Derşida, green triangles - Palatca.

Furthermore, there is also a tendency for lower $\mathrm{Cr}$ and $\mathrm{Ni}$ values in Derşida but again not clear separation. A distinct separation among both groups is shown only by the Cs content (Fig. 4f), with about 6 ppm in Palatca and 4 ppm in Derşida.

The accuracy and the precision of the Cs determination is in the range of $0.4 \mathrm{ppm}$ and $0.2 \mathrm{ppm}$ respectively, which allows for a clear separation. In the ceramics, Cs can have two sources: either from the matrix clay (silt) and/or from the temper minerals. According to Cullers (1994) shales and clays can incorporate up to $30 \mathrm{ppm} \mathrm{Cs}$, silts and sands less up to 9 and $7 \mathrm{ppm}$ Cs respectively. On the other hand, Cs can be inluded in the K-bearing minerals (compare Murariu, 2002) such as feldspar (up to $30 \mathrm{ppm}$ ), muscovite (approx. $20 \mathrm{ppm}$ ) and particular in biotite (up to 200 ppm). Minor amounts of Cs also occur in amphiboles. The temper clasts from Derşida are derived mainly from metamorphics from the Northern Apuseni Mts. and contain frequently biotite, muscovite, amphiboles and to a lesser extent K-feldspar. These minerals can contribute significantly to the overall Cs concentration in these samples. The Palatca clastics are derived from the Neogene volcanics, with plagioclase, K-feldspar and rare biotite.
Despite the higher amount of potential Cs-bearing minerals, the Derşida samples show consistently lower Cs value than Palatca, where such minerals are rare. This argues in turn for already different Cs levels in the matrix clays (silts) between Derşida and Palatca.

REE and Spider diagrams (Figs. 5a-f and 6a-f). The normalisation of the REE and other trace elements against those from mantle, crust or MORB is a powerful tool in magmatic petrology to infer magmatic processes. This approach may be also used in interpreting ancient ceramics. Normalizing the REE against various average shales such as North American Shale Composite (NASC; Gromet et al., 1984), Post Archean Australian Shale (PAAS; Taylor and McLennan 1985; Nagarajan et al., 2007) or European Shale (ES; Haskin and Haskin, 1966), similar patterns appear for all samples (Copăceni - Fig. 5a, Derşida - Fig. 5c, Palatca - Fig. 5e), consistent with the results for other trace elements. For simplicity only the NASC normalized patterns are shown.

Generally, the REE concentration of the ceramics normalized against NASC is slightly below 1, varying from 0.6 to 1 . Few samples are above 1 for the LREE. The overall pattern is almost flat with a minor variation, as for exmple a small relative enrichment of $\mathrm{Ce}$ or a small depletion of Er. Normalized with NASC, a negative Eu 
anomaly is observed in Copăceni B samples and to a lesser extent in Copăceni A.

The Upper Continental Crust (UCC; Rudnik and Gao, 2003) normalized patterns are close to unity, with the MREE and the HREE slightly above (Figs. 5 b,d,f). The low concentration of REE in the ceramics compared with the shales is probably due to the temper but it brings at the same time the ceramics close to the average upper

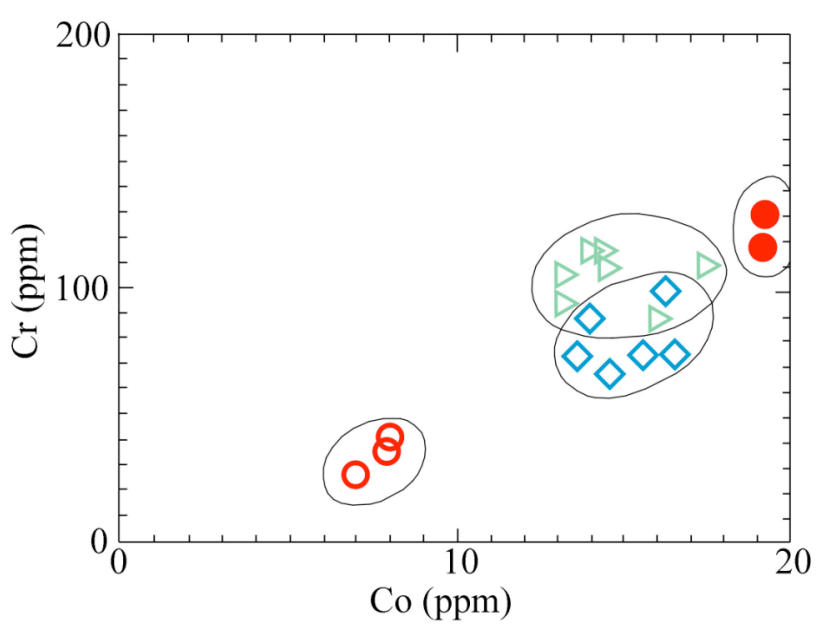

a)

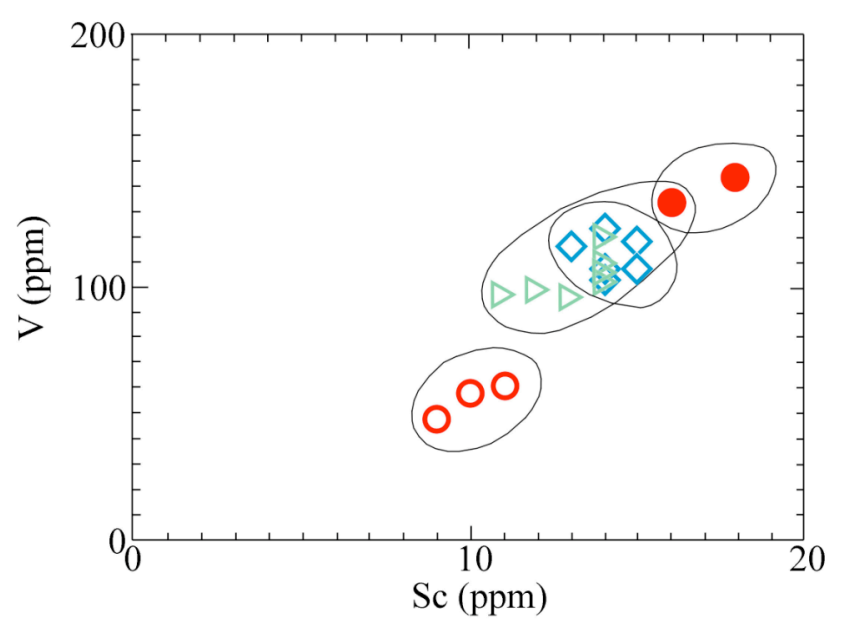

c)

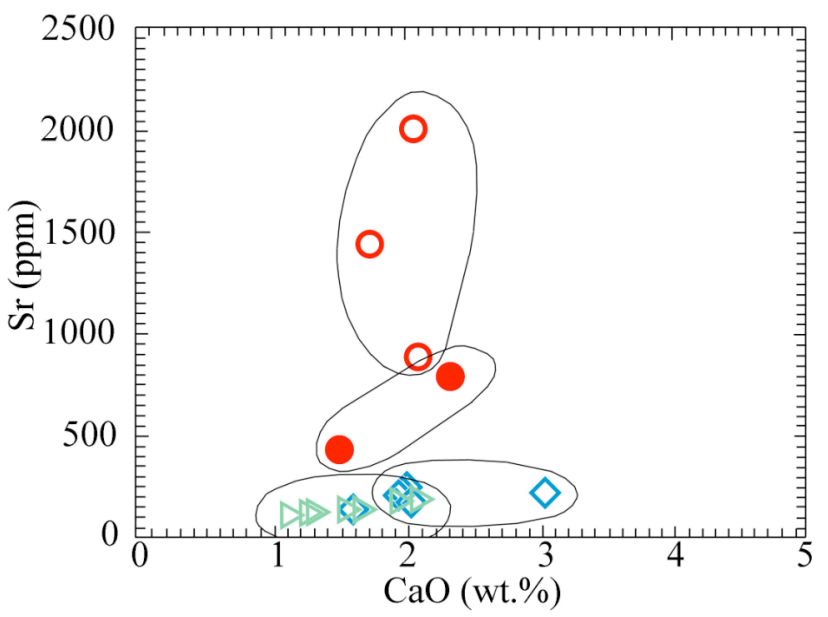

e) continental crust. It should be noted here that the ( $\mathrm{La} / \mathrm{Yb}) \mathrm{N}$ ratio is $>1$ for NASC and $<1$ for the UCC normalization. The Copăceni A group has a higher REE content than Copăceni B except for the sample 36-1 which exhibits the highest REE concentration in particular for $\mathrm{Sm}, \mathrm{Gd}, \mathrm{Tb}$, Dy, due to a singular occurrence of a REEbearing mineral, probably allanite. In 36-1 $\mathrm{Ce}$ and $\mathrm{Eu}$ values are lower than for Copăceni A.

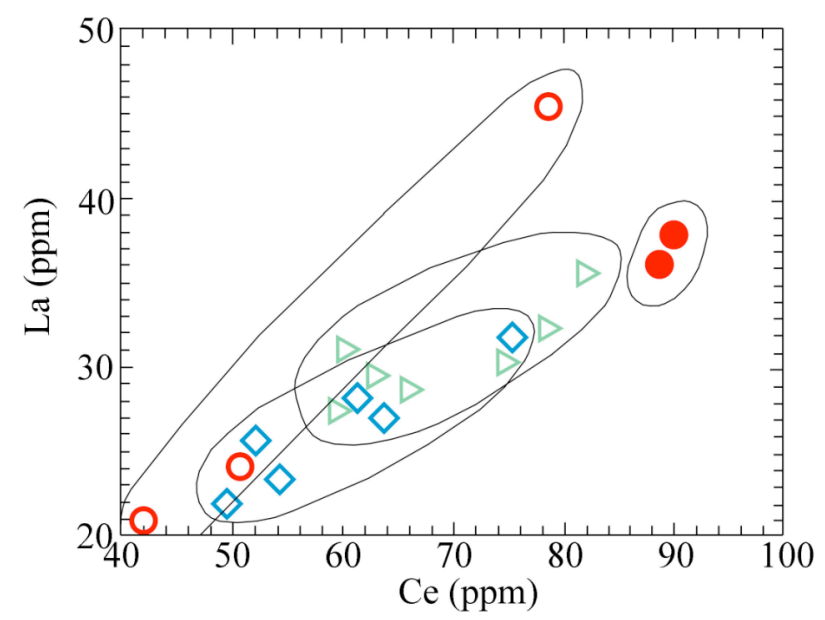

b)

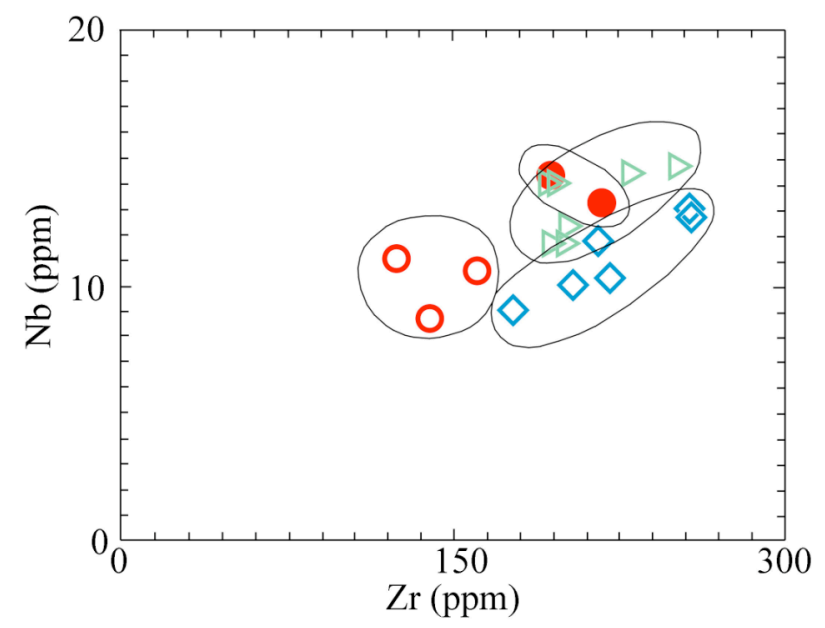

d)

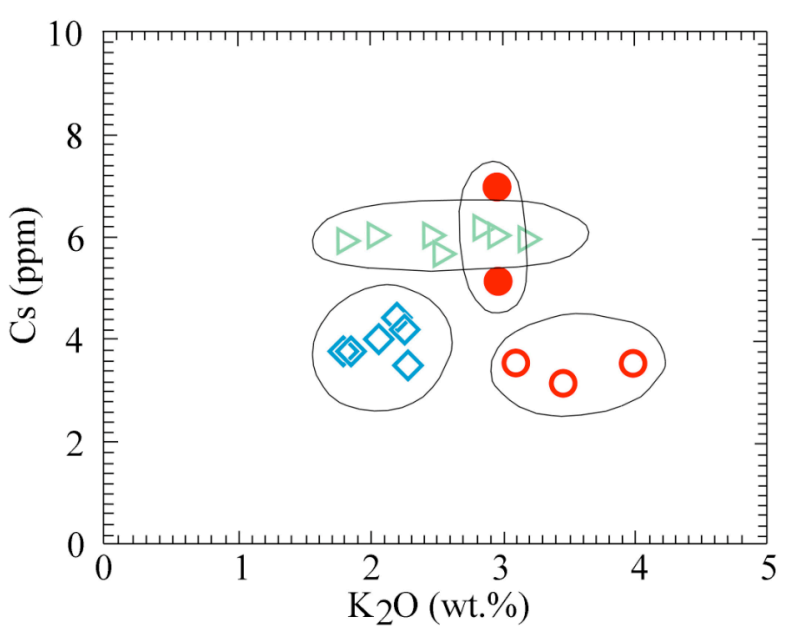

f)

Fig. 4. Plot of the ceramics composition in the a) $\mathrm{Co} / \mathrm{Cr}$, b) $\mathrm{Ce} / \mathrm{La}$, c) $\mathrm{Sc} / \mathrm{V}, \mathrm{d}) \mathrm{Zr} / \mathrm{Nb}$, e) $\mathrm{CaO} / \mathrm{Sr}$ and f) $\mathrm{K} 2 \mathrm{O} / \mathrm{Cs}$ diagrams. Legend: full red circles - Copăceni A, empty red circles - Copăceni B, blue diamonds - Derşida, green triangles - Palatca. 


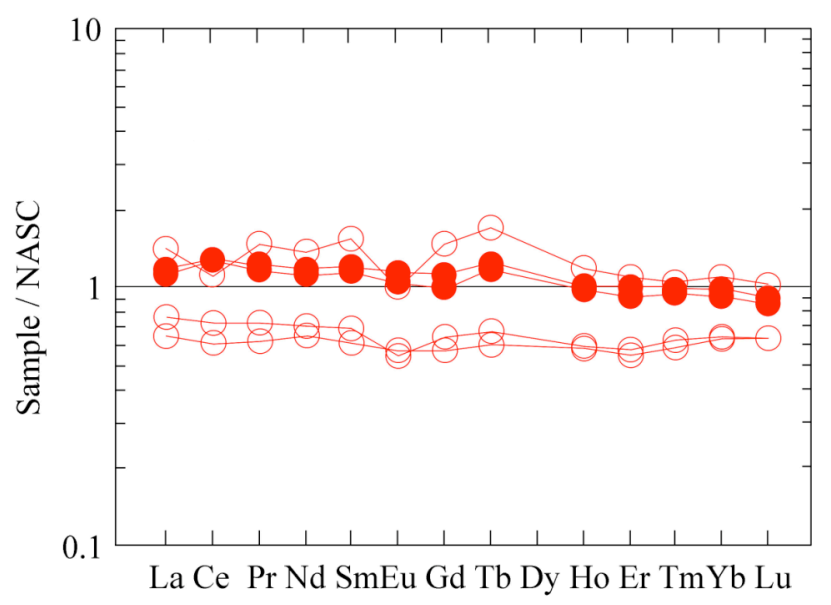

a)

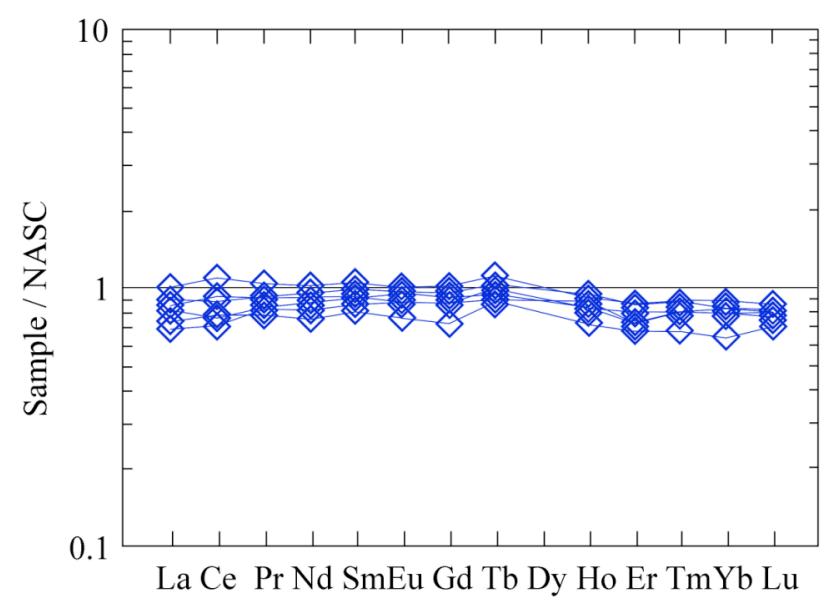

c)

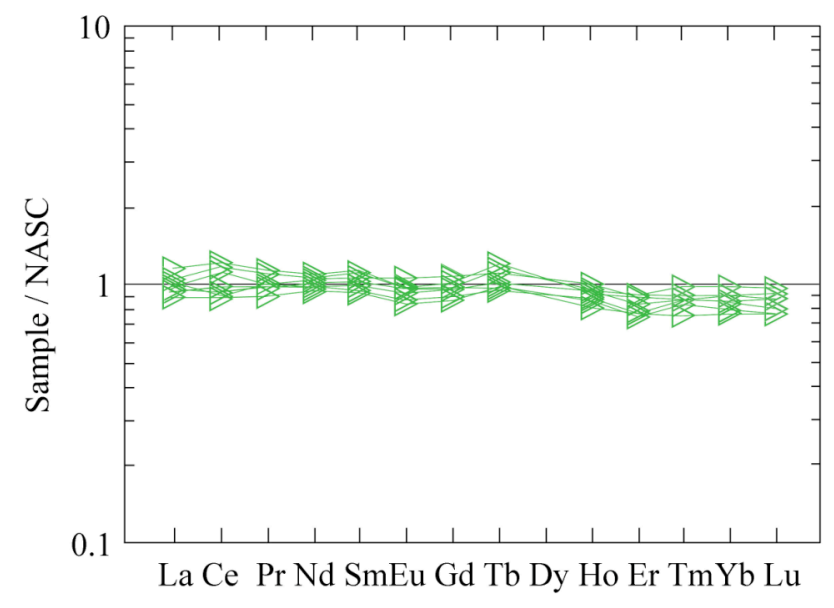

e )

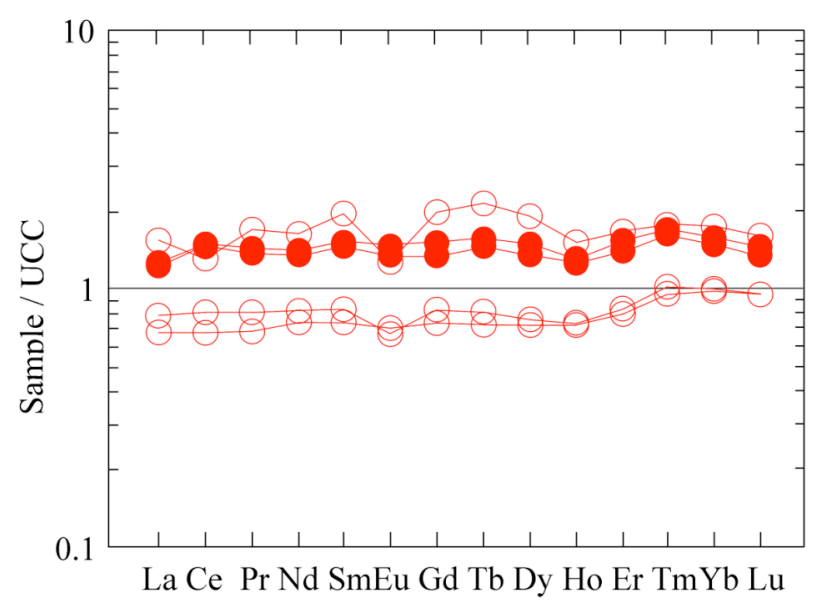

b)

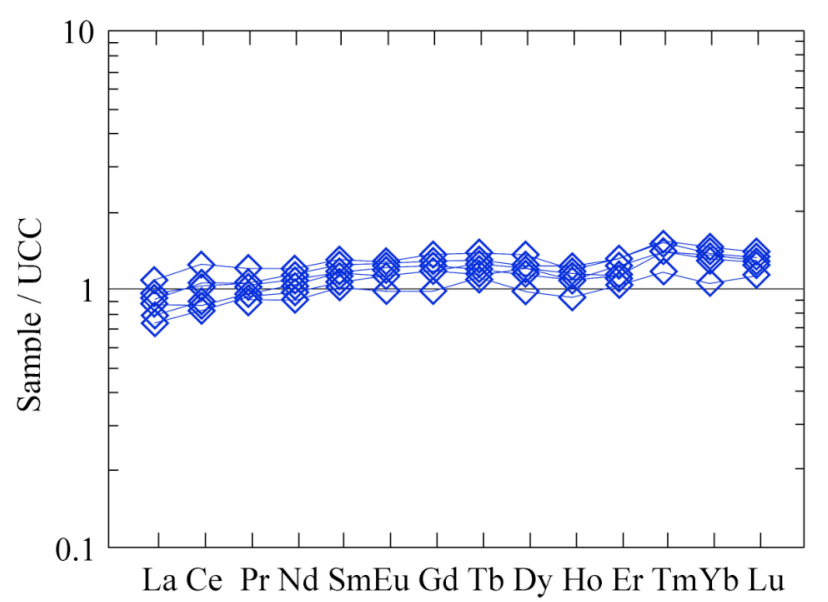

d)

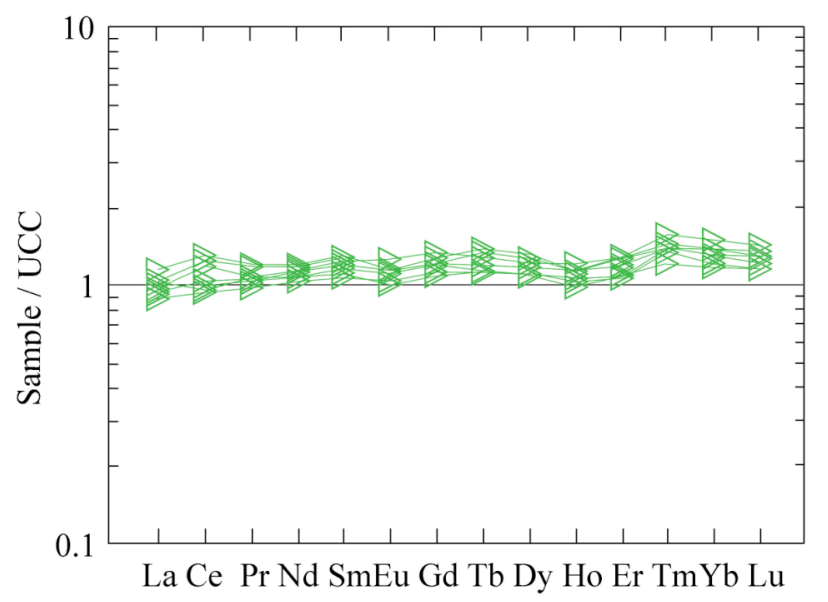

f)

Fig. 5. REE diagrams for Copăceni (a, b), Derşida (c, d) and Palatca (e, f) samples, normalized to NASC (Gromet et al., 1984) (a, c, e) and UCC (Rudnik and Gao, 2003) (b, d, f). Legend: full red circles - Copăceni A, empty red circles - Copăceni B, blue diamonds - Derşida, green triangles - Palatca.

The spider diagrams (Figs. 6a-f) normaliyed against NASC display similar results (Figs. 6 a, c, e). The patterns are slightly below unity with some irregularirties. $\mathrm{Rb}$, is low in all groups, K in Copăceni A, Derşida and Palatca, Ti only in Copăceni B and Cs in Derşida. Ba and Y are high in all samples, Th only in the Copăceni groups. The positive $\mathrm{Sr}$ anomaly in Copăceni (Fig. 6a) is clearly visible. Additionally, Derşida exhibits a small positive $\mathrm{Sr}$ anomaly (Fig. 6c) which is not seen in Palatca (Fig. 6e). Sample 36-1 from Copăceni B is highest in the REE, Y, Studia UBB, Geologia, 2009, 54 (2), 41 - 51
$\mathrm{Ba}$, and $\mathrm{Th}$ but low in the other elements. Normalized against the UCC, the pattern is more close to 1 , only the elements between $\mathrm{Zr}$ and $\mathrm{Yb}$ are slightly above (Fig. 6b). As a whole, the it is more smooth except for $\mathrm{Sr}$, with a positive anomaly for Copăceni $\mathrm{A}$ and $\mathrm{B}$, but contrast to the NASC normalization with a negative anomaly for Derşida and Palatca, which is due to the high Sr values of UCC. The low Ti (due to low Ti content of the acidic volcanics derived temper) values remain for the Copăceni B samples (Fig. 6a). 


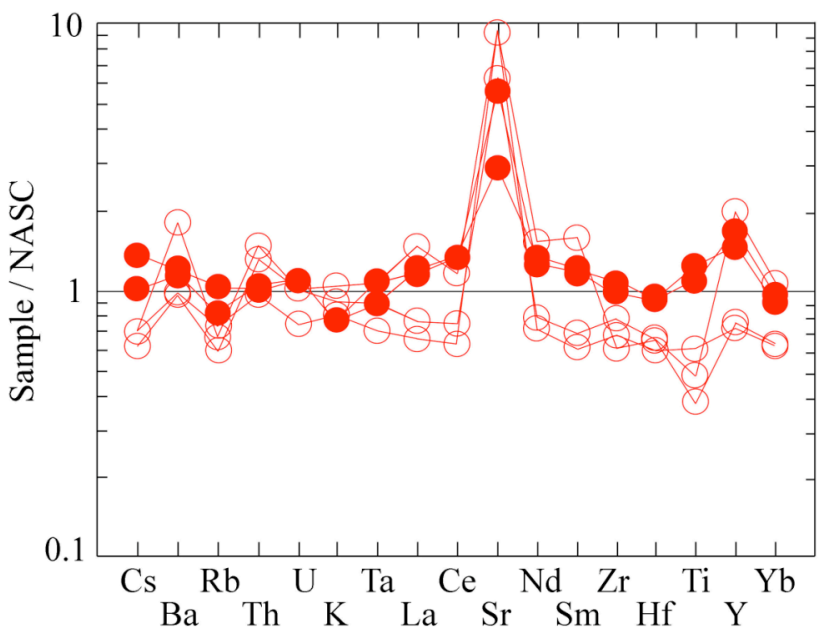

a)

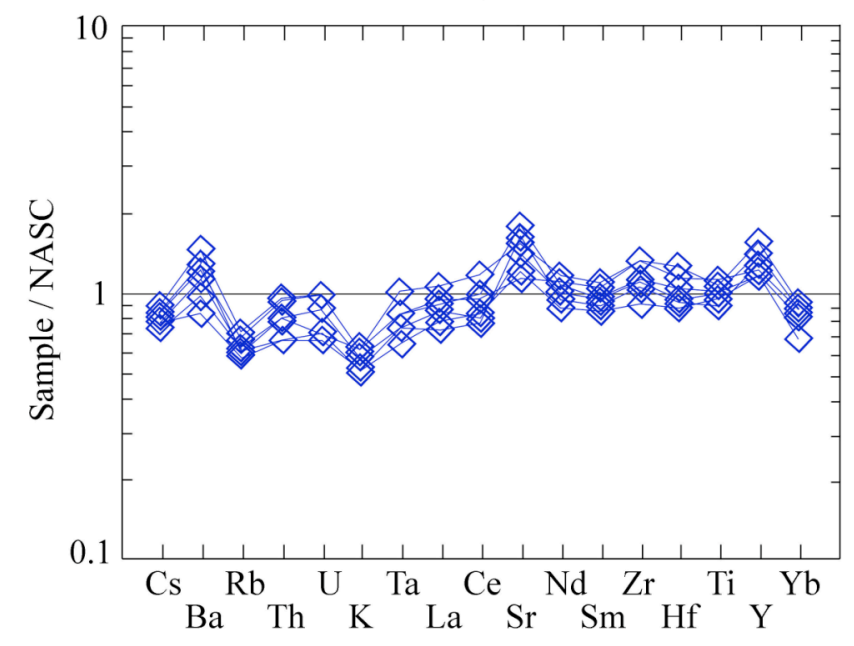

c)

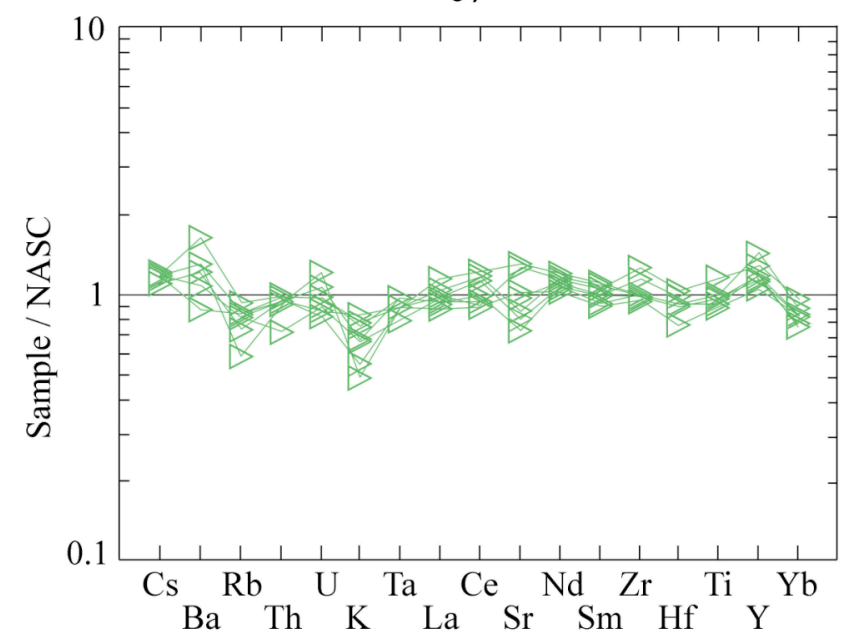

e)

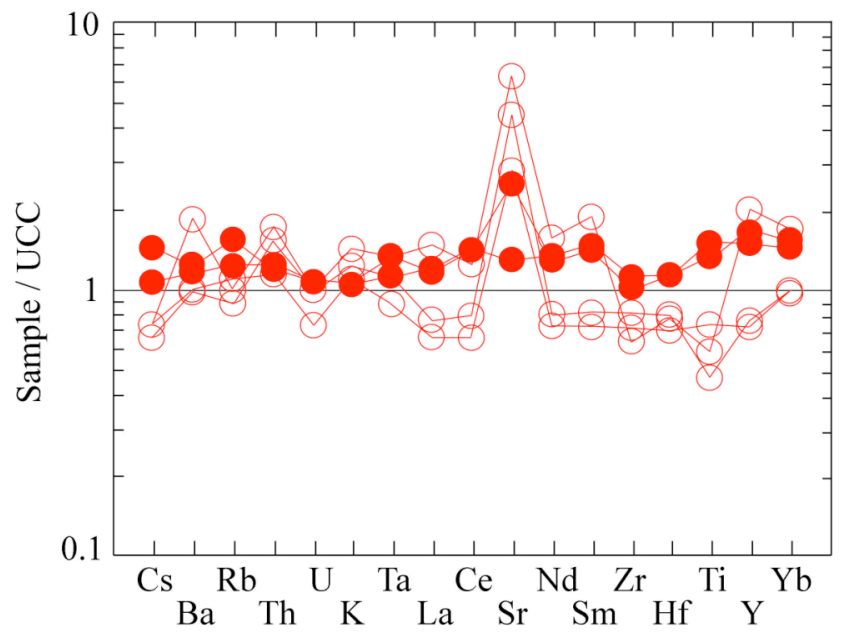

b)

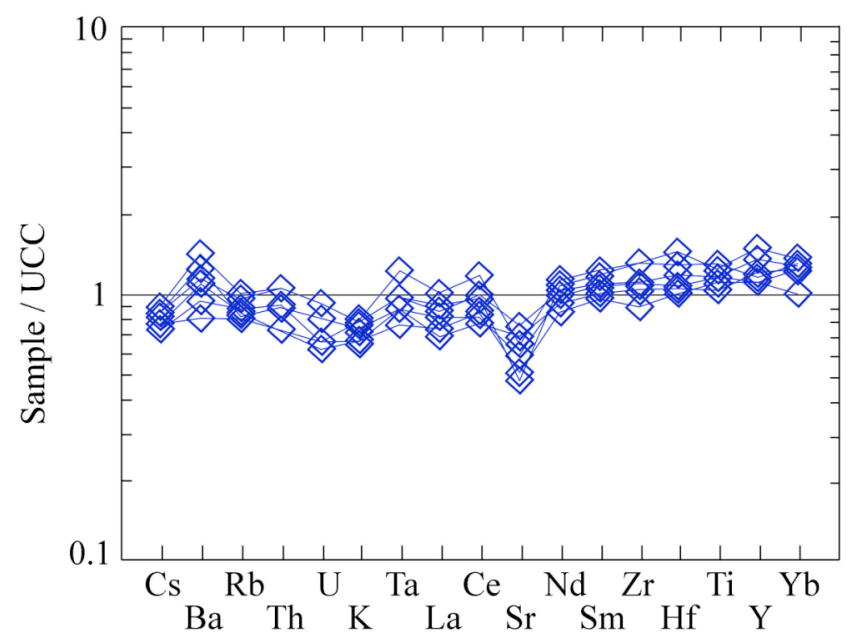

d)

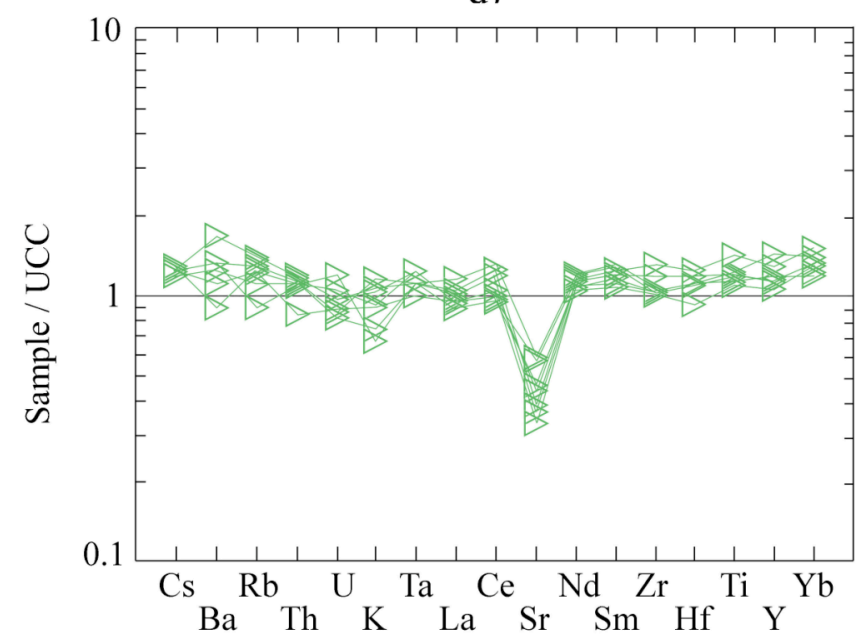

f)

Fig. 6. Spider diagrams for Copăceni (a, b), Derşida (c, d) and Palatca (e, f) samples normalized to NASC (Gromet et al., 1984) (a, c, e) and UCC (Rudnik and Gao, 2003) (b, d, f). Legend: full red circles - Copăceni A, empty red circles - Copăceni B blue diamonds - Derşida, green triangles - Palatca.

Like the bivariate diagrams, the REE normalized and the spider diagrams also sort out clearly Copăceni B from the rest. Both Copăceni groups are distinct in their anomalous high $\mathrm{Sr}$ content (Figs. $6 \mathrm{a}, \mathrm{b}$ ). Derşida (Figs. 6 c, d) and Palatca (Figs. 6 e, f) samples overlap largely, the former showing a trend to lower normalized values. The shale normalized patterns, as shortly discussed above, are below 1 regarding mainly REE and spider diagrams equally. For the interpetation, the nature of the temper minerals is important. Pyroxene, amphibole, biotite, muscovite and opaque minerals contribute to the REE and partly to several other trace elements in Copăceni 
A and Derşida. The acidic volcanic fragments, quartz and feldspars forming almost exclusively the temper in Copăceni B and Palatca cause more likely a dilution of the total REE budget. This difference is well visible within the both Copăceni groups, but not discernable between Palatca and Derşida. Most likely the clays were already variably depleted in respect to the REE and trace elements such as $\mathrm{Ti}, \mathrm{U}, \mathrm{Pb}, \mathrm{Nb}$, and $\mathrm{Cs}$ concentration. The $(\mathrm{La} / \mathrm{Yb}) \mathrm{N}$ ratios point in the same direction. They are, depending on the norm values, similar for all groups despite the highly variable temper material suggesting also differences in the REE content in the raw clays.

\section{CONCLUSIONS}

The discussion of the chemical data and their interpretation, in terms of mineralogy, showed that the variability of the chemistry is to a considerable part determined by minerals such as quartz, feldspars, pyroxene, amphibole, micas, opaque minerals and the according lithoclasts including metamorphics, acidic or basic volcanics and plutonics.

Despite the relative small database, a careful analysis of the chemistry combined with the mineralogy, allows to characterize the Bronze Age ceramics from the three locations and to separate out the subgroups $\mathrm{A}$ and $\mathrm{B}$ for Copăceni. Based on major elements, such as $\mathrm{Al}_{2} \mathrm{O}_{3}, \mathrm{TiO}_{2}$ and $\mathrm{K}_{2} \mathrm{O}$, the Copăceni B subgroup could be sorted out not only from Copăceni A but also from Derşida in a relatively simple way. The exceptional REE concentrations of sample 36-1 from Copăceni B are probable due to the presence of allanite. Derşida is well separated from both Copăceni groups in terms of major and trace elements. Due to their wide spread element concentration compared with the other groups the Palatca samples overlap to a certain extent with Copăceni $\mathrm{A}$, the distinction from Copăceni B is more clear. The most difficult is the distinction between Derşida and Palatca. Both groups are sorted out - not always accurately - by their $\mathrm{Na}_{2} \mathrm{O} / \mathrm{K}_{2} \mathrm{O}$, $\mathrm{Zr} / \mathrm{Nb}$ ratios and the Cs content.

The chemistry contributes also to the identification of raw material sources, in particular the temper. Copăceni A was separated out, among other elements, by the positive $\mathrm{Sr}$ anomaly. It is an excellent evidence that the Copăceni raw material was mined at a close distance from the Badenian celestine-bearing sediments. Whereas Copăceni A has an important contribution from the metamorphic basement of the Northern Apuseni units, with acidic and basic rock fragments and minerals, including opaque phases, the mineralogy in Copăceni B is documented by intermediate and acidic volcanics derived from the Jurassic Island Arc Volcanics. This difference in mineralogy is clearly reflected in the chemisty of the ceramics. The temper material for the first group were most likely alluvial sediments of the Hăşdate brook. These alluvias contain fragments of the Apuseni metamorphics showing basic and acidic composition. For Copăceni B the most probable source is then the Racilor creek, NNW of Copăceni.

The temper material was collected in relatively close vicinity of the sites. This is in particularly true for the Copăceni, with a strong $\mathrm{Sr}$ anomaly indicating the Badenian source. In Derşida, metamorphic rocks and to a smaller extent intermediate and acidic volcanics were collected as temper from the Crasna Mare river sediments nearby This river has its springs in the metamorphic rocks of the Northern Apuseni units (Meseş Mts.). Besides the metamorphic material it also takes some Neogene volcanics downhill. More complicated is the situation in Palatca, located in the Transylvanian Basin. Chemistry and mineralogy indicate intermediate to acidic volcanics together with some metamorphics as major temper material. Presently, there is no river catchment which could collect such material from either the Eastern Carpathians or the Apuseni Mts., but the Sarmatian sediments include clastic sequences with volcanic and metamorphic clasts, which could be derived from the geological surroundigs of the Transylvanian Basin, probably from the $\mathrm{NE}$ in the Sarmatian times. In the absence of an appropriate stream catchment we suppose that the raw materials of the ceramics were collected from outcrops of Sarmatian silts and sands.

The geochemical analyses from three sites assigned to the Bronze Age contain data including major elements, trace elements and REE. They are the first complete data set on Bronze Age ceramics in Romania and were linked with their mineralogical composition. Although the quantity of analyses is not too large they can serve as a basis for a geochemical reference set used by further studies.

Acknowledgements. The authors are grateful to Prof. Dr. Isabella Memmi Turbanti (Siena University) and Prof. Dr. Friedrich Koller (University of Vienna) for suggestions which helped to improve the manuscript. We acknowledge thankfully the computer-assisted drawings by Mrs. Monica Mereu (Babeş-Bolyai University of Cluj-Napoca). The study was financially supported by ID-2241 Grant (Romanian Ministry of Education).

\section{R E F E R E N C E S}

Barone, G., Lo Giudice, A., Mazzoleni, P., Pezzino, A., Barilaro, D., Crupi, V. \& Triscari, M. 2005. Chemical characterization and statistical multivariate analysis of ancient pottery from Messina, Catania, Lentini and Siracusa (Sicily). Archaeometry, 47 (4): 745-762.

Belfiore, C.M., Day, P.M., Hein, A., Kilikoglou, V., La Rosa, V., Mazzoleni, P. \& Pezzino, A. 2007, Petrographic and chemical characterization of pottery production of the Late Minoan I kiln at Hagia Triada, Crete. Archaeometry, 49 (4): 621-653.

Chidioşan, N. 1980, Contributions to the study of the Thracians from the north-western part of Romania. The Wietenberg-type site from Derşida. Muzeul T,ării Crişurilor, 136 p., Oradea (in Romanian).

Ciupagea, D., Pauca, M. \& Ichim, T. 1970, Geology of the Transylvanian Depression. Ed. Academiei, 254 p., Bucharest (in Romanian).

Cox, R., Lowe, D.R. \& Cullers, R.L. 1995, The influence of sediment recycling and basement composition on evolution of mudrock chemistry in the southwestern United States. Geochimica et Cosmochimica Acta, 59 (14): 2919-2940.

Cullers, R.L. 1994, The controls of the major and trace elements variation of shales, siltstones, and sandstones of Pennsylvanian-Permian age from uplifted 
continental blocks in Colorado to platform sediment in Kansas, USA. Geochimica et Cosmochimica Acta, 58 (22): 4955-4972.

Ghergari, L. Lazarovici, Gh., Ionescu, C. \& Tămaş, T. 1999, Geoarchaeological studies on some ceramic artefacts from the Early Neolithic site of Lunca-Poiana Slatinii, Neamț County (Romania). Angvstia, 4: 1-7 (in Romanian).

Giuşcă, D., Bleahu, M., Lupu, M., Borcoş, M., Lupu, D. \& Biţoianu, C. 1967, Geological Map of Romania, 1:200,000 scale, Şimleul Silvaniei Sheet, Geological Institute Bucharest.

Gliozzo, E., Memmi Turbanti, I. 2004, Black gloss pottery: production sites and technology in northern Etruria. Part I: provenance studies. Archaeometry, 46: 201-227.

Gromet, L.P., Dymek, R.F., Haskin, L.A. \& Korotev, R.L. 1984, The North American shale composite: its compilation, major and trace element characteristics. Geochimica et Cosmochimica Acta, 48: 2469-2482.

Haskin, M.A., Haskin, L.A. 1966, Rare earths in European shales - A redetermination. Science, 154: 507-509.

Imreh, J., Imreh, G. 1959, Coelestin-Krystalle aus Cheia. Neues Jahrbuch für Mineralogie Monatshefte, Jg. 1959, p. 11-12.

Ionescu, C., Ghergari, L., Hoeck, V. \& Simon, V. 2007a, Firing transformations in Late Bronze Age ceramics from Transylvania (Romania). In Vessels: inside and outside (Biro, K.T., Szilagyi, V. \& Kreiter, A., Eds.). Hungarian National Museum, p. 38, Budapest.

Ionescu, C., Hoeck, V. \& Ghergari, L. 2007b, Postdepositional chemical and mineralogical alteration of Late Bronze Age ceramic artefcats (Transylvania, Romania). In Vessels: inside and outside (Biro, K.T., Szilagyi, V. \& Kreiter, A., Eds.). Hungarian National Museum, p. 113, Budapest.

Ionescu, C., Ghergari, L., Hoeck, V., Simon, V. \& Horga, M. 2006, Thermal alteration of mineral phases in Bronze Age ceramics from Transylvania (Romania). In Abstracts Book $3^{\text {rd }}$ Mid-European Clay Conference, $p$. 58, Opatija.

Ionescu, C., Ghergari, L., Simon, V., Horga, M. \& Hoeck, V. 2005, Geoarchaeological studies on Late Bronze Age ceramics from Transylvania (Romania). Mitteilungen der Österreische Mineralogische Gesselschaft, 15: p. 52, Graz.

Ionescu, C., Hoeck, V. 2008, Composition and fabric of ancient ceramics: a mineralogical and petrographic perspective. In Program and abstracts of the $37^{\text {th }}$ International Symposium on Archaeometry, p. 151, Siena.

Lupu, M., Borcoş, M., Dimian, M., Lupu, D. \& Dimitrescu, R. 1967, Geological map of Romania, 1:200,0000 scale, Turda Sheet. Geological Institute Bucharest.

Mirti, P., Gulmini, M., Pace, M. \& Elia, D. 2004, The provenance of red figure vases from Locri Epizephiri (Southern Italy): new evidence by chemical analysis. Archaeometry, 46 (2): 183-200.

Murariu, T. 2002, The geology and geochemistry of ore deposits. Junimea Iaşi, 531 p. (in Romanian).

Nagarajan, R., Madhavaraju, J., Nagendra, R., ArmstrongAltrin, J.S. \& Moutte, J. 2007, Geochemistry of Neoproterozoic shales of the Rabanpalli formation,
Bhima Basin, Northen Karnataka, southern India: implications for provenance and paleoredox conditions. Revista Mexicana de Ciencias Geológicas, 24 (2): 150-160.

Precup, C. 2008, The Bronze Age ceramics from Transylvania: mineralogical and technological characteristics. PhD Thesis, Babeş-Bolyai University, Cluj Napoca, 189 p.

Precup, C., Ionescu, C. \& Ghergari, L. 2006a, Mineralogical and petrographical study of Middle Bronze Age ceramics from Derşida (NW Transylvania, Romania). Acta Mineralogica-Petrographica, Abstr. series, 5: p. 99.

Precup, C., Ionescu, C., Ghergari, L., Hoeck, V. \& Simon, V. 2006b, A study of Bronze Age pottery from Transylvania, Romania. In Proceedings XVIII ${ }^{\text {th }}$ CBGA Congress, 478-481, Belgrade.

Precup, C., Ionescu, C., Hoeck, V., Ghergari, L. 2007, Bronze Age pottery from Transylvania (Romania): a mineralogical study. In Vessels: inside and outside (Biro, K.T., Szilagyi, V. \& Kreiter, A., Eds.). Hungarian National Museum, p. 126, Budapest.

Precup, C.N., Ionescu, C., Hoeck, V. \& Ghergari, L. 2008, Comparative study of Bronze Age ceramics from Transylvania. In Program and abstracts $37^{\text {th }}$ International Symposium on Archaeometry, p. 180, Siena.

Răileanu, G., Saulea, E., Dumitrescu, I., Bombiță, Gh., Marinescu, F., Borcoş, M. \& Stancu, J. 1967 Geological map of Romania, 1:200,000 scale, Cluj Sheet, Geological Institute Bucharest.

Rotea, M. 1993, Contributions about the Early Bronze Age in the center of Transylvania. Thraco-Dacica, XIV (1-2): 65-86 (in Romanian).

Rotea, M. 1997, Archaeological studies at Palatca. Preliminary notes. Revista Bistriței, X-XI: 13-19.

Rudnik, R.L., Gao, S. 2003, Composition of the continantal crust. In The Crust (Rudnik, R.L., Ed.). Treatise on Geochemistry, 3: 1-64.

Savul, M., Ianovici, V., Imreh, I., Imreh, G. 1964, Chemistry of some bituminous limestones from the NW part of the Transylvanian Basin. Studii şi Cercetări de Geologie Geofizică Geografie, Seria Geologie, 9 (2): 371-397 (in Romanian).

Szakacs, A. 2000, The petrologic and tephrologic study of the lower badenian volcanic tuffs from the NW part of the Transylvanian Basin. PhD. Thesis, Bucharest University, $216 \mathrm{p}$.

Taylor, S.R., McLennan, S. 1985, The continental crust: its composition and evolution. Blackwell, Oxford, $312 \mathrm{p}$.

Yoon, Y.Y., Lee, K.Y., Chung, K.S., Yang, M.K. \& Kim, K.H. 2001, Classification of Korean old potteies by trace elements analysis. Journal of Radioanalytical and Nuclear Chemistry, 248 (1): 89-92. 